\title{
ANALISIS KEPADATAN NYAMUK MENGGUNAKAN LIGHT TRAP PADA KEJADIAN MALARIA
}

\author{
Hasan Husin \\ Universitas Muhammadiyah Bengkulu, Program Studi Ilmu Kesehatan Masyarakat \\ Jl. Salak Raya Lingkar Timur Bengkulu \\ hasanhusin355@gmail.com
}

\begin{abstract}
Light Trap is a mosquito catcher by using light to trap mosquito into a research container. The study objective was to find out the relationship between the density of anopheles mosquitoes with malaria incidence in Taba Lagan Village, Central Bengkulu. This research is quasi-experiment with quantitative approach. The population of this study was all of mosquitos breeding place data and all of patients data who got treatment at community health centre of Tabalagan. Samples of the study were selected by using proportional random sampling. The results showed that the density of mosquitoes about 127 in cowshed which had some characteristics such as bigger size than another mosquito and they used to come out about 06.00 to 10.00 PM. There were 96 medium-sized mosquitoes at rubber plantation which had activity around 05.00 AM. While there were 38 small-sized mosquitoes which are living around cluster residents environment and usually bit human about 06.00 to $09.00 \mathrm{PM}$. In concluding, the largest number of anopheles mosquitoes was in cowshed $(0.118 \%)$ with malaria cases of 6 people and who are living about 10 to 20 meters nearby cowshed.
\end{abstract}

Keywords: Anopheles Mosquito Density, Light Trap, Malaria

\begin{abstract}
Abstrak: Light Trap adalah alat penangkap nyamuk dengan menggunakan cahaya lampu untuk menjebak nyamuk supaya masuk ke dalam wadah yang dipasang pada saat penelitian. Tujuan penelitian adalah diketahuinya kepadatan nyamuk anopheles yang tertangkap dengan kejadian malaria di Desa Taba Lagan Bengkulu Tengah. Penelitian ini adalah quasi expriment dengan pendekatan kuantitatif. Populasi penelitian adalah seluruh data tempat perindukan nyamuk dan data pasien berobat di puskesmas tabalagan. Sampel diambil dengan proportional random sampling. Hasil penelitian menunjukkan kepadatan nyamuk di kandang kerbau 127 ekor dengan ciri-ciri nyamuk lebih besar dan aktivitas nyamuk keluar pukul 18.00 sampai 22.00 wib, perkebunan karet 96 ekor nyamuk berukuran sedang dengan aktivitas nyamuk mencari pakan darah pukul 05.00 wib, serta lokasi perkumpulam penduduk 38 ekor berukuran kecil, aktivitas nyamuk menggigit antara pukul 18.00 sampai 21.00 wib. Hasil penangkapan nyamuk anopheles terbanyak yaitu pada kandang kerbau $(0,118 \%)$ dengan kasus malaria sebanyak 6 orang, hal ini disebabkan karena warga tinggal didekat kandang kerbau yang berjarak 10 sampai 20 meter.
\end{abstract}

Kata Kunci: Kepadatan Nyamuk Anopheles, Light Trap, Malaria

Malaria adalah penyakit yang disebabkan oleh parasit protozoa dari genus plasmodium yang menyebabkan kurang lebih 3 juta kasus malaria dan 1,5 hingga 2,7 juta meninggal dunia setiap tahun. Ada lima spesies plasmodium penyebab malaria pada manusia, yaitu plasmodium vivax, plasmodium falcifarum, plasmodium malariae, plasmodium ovale dan plasmodium knowlessi. Masing-masing spesies plasmodium menyebabkan infeksi malaria vivax/tertiana, plasmodium falcifarum menyebabkan malaria falcifarum/ tropika, plasmodium ovale menyebabkan malaria ovale dan knowlessi. 
Penyakit malaria ditularkan melalui gigitan nyamuk anopheles betina infektif. Sebagian besar nyamuk anopheles akan menggigit pada waktu senja atau malam hari, pada beberapa jenis nyamuk puncak gigitannya adalah tengah malam sampai fajar (Depkes RI, 2009).

Malaria ditemukan di negara-negara yang beriklim tropis dan sub tropis, terutama di negara-negara benua Afrika. Penduduk yang berisiko terkena malaria berjumlah sekitar 2,3 miliar atau $41 \%$ dari jumlah penduduk.

Penyebaran malaria di dunia sangat luas yakni antara garis bujur $60^{\circ}$ di utara dan $40^{\circ}$ di selatan yang meliputi lebih dari 100 negara yang beriklim tropis dan sub tropis. Penduduk yang berisiko terkena malaria berjumlah sekitar 2,3 miliar atau $41 \%$ dari penduduk dunia. Setiap tahun jumlah kasus malaria berjumlah 300-500 juta mengakibatkan 1,5 s/d 2,7 juta kematian, terutama di Benua Afrika sub sahara. Wilayah di dunia yang kini sudah bebas malaria adalah Eropa, Amerika Utara, sebagian besar Timur Tengah, sebagian besar Kariba, Amerika Selatan, Australia dan Cina. Ketinggian yang memungkinkan parasit malaria hidup adalah 400 meter dibawah permukaan laut dan 2600 meter diatas permukaan laut (Probowo A, 2004).

Keberhasilan pembangunan pada suatu wilayah sangat ditentukan oleh ketersediaan sumber daya manusia yang berkualitas, dimana pembangunan sektor kesehatan merupakan salah satu unsur penentu. Untuk mendapatkan sumber daya manusia yang berkualitas, masyarakat harus bebas dari berbagai penyakit termasuk malaria (Widoyo, 2005).

Setiap tahun kasus malaria berjumlah sekitar 300-500 juta kasus dan mengakibatkan 1,5 - 2,7 juta kematian, yang terdapat di seluruh bagian dunia (Prabowo, 2004).

Penyakit malaria menurut hasil pemeriksaan darah dari penderita malaria positif diberbagai kabupaten yaitu
Bengkulu Selatan berjumlah 30 penderita, Kaur berjumlah 3.018 penderita, seluma berjumlah 4,601 penderita, di Muko-muko terdapat 3,802 penderita, di Lebong terdapat 3 penderita, Bengkulu Tengah terdapat 5,540 penderita, dan di kota Bengkulu berjumlah 7,335 penderita. Tingginya kejadian malaria karena daerah endemis malaria yang merupakan daerah pantai beriklim panas, banyak terdapat hutan dan perkebunan di Provinsi Bengkulu (Dinas Kesehatan Provinsi Bengkulu, 2011).

Data pada tahun 2010 terdapat 16.149 penderita malaria klinis dan malaria positif adalah 1.843 dan tahun 2011 malaria klinis 14.292 dan malaria positifnya adalah 1.042 penderita. Malaria masih merupakan penyakit menular yang masih menjadi masalah kesehatan di Kota Bengkulu (Dinkes Kota Bengkulu, 2011).

Propinsi Bengkulu memiliki 9 Kabupaten dan 1 kota madya. Kabupaten Bengkulu Tengah merupakan Kabupaten baru yang memiliki jumlah penduduk 10.675 jiwa, berdasarkan data dari Dinas kesehatan Propinsi Bengkulu, Kabupaten Bengkulu Tengah merupakan penyumbang kasus malaria tertinggi keempat setelah kabupaten Muko-Muko, Kabupaten Bengkulu Utara dan Kota Bengkulu API (Annual Paracite Incindence) Bengkulu Tengah pada tahun 2011 adalah 3,15\% penduduk sedangkan AMI (Annual malaria Incindence) pada tahun 2011 adalah $77,82 \%$ penduduk (Dinas Kesehatan Bengkulu Tengah, 2011).

Desa Tabalagan terdapat 852 penduduk dengan jumlah KK 376, Masalah lingkungan yang mendukung perkembangan nyamkuk anopheles yaitu disebabkan kondisi daerah yang potensial menjadi tempat perindukan dan perkembangbiakan yamuk anopheles, yaitu kandang kerbau $75 \%$, hutan $60 \%$, limbah $60 \%$, rawa-rawa $65 \%$, kandang pertenakan $75 \%$, dengan kasus malaria 65 orang pada tahun 2012 (Puskesmas Tabalagan, 2012). 
Light trap merupakan salah satu alat penangkap nyamuk, dalam kegiatan survei vektor. Alat ini menggunakan sinar lampu, karena nyamuk sangat tertarik pada cahaya (phototropic), dengan lampu yang digunakan adalah lampu listrik 20 watt sebagai penarik nyamuk. Light trap merupakan salah satu metode untuk mengetahui kepadatan populasi nyamuk anopheles $s p$ guna pimilihan metode pengendalian vektor malaria.

Tujuan penelitian ini adalah diketahuinya kepadatan anopheles sp menggunakan light trap dengan kejadian malaria di Desa Taba Lagan Bengkulu Tengah. Metode penelitian ini bersifat eksperimen dengan menggunakan lampu light trap dan mengetahui jumlah nyamuk anopheles $s p$ yang tertangkap dengan menggunakan cahaya lampu light trap. diletakkan ditempat seperti rumah yang berada didekat kandang kerbau, didekat kebun karet, dan rumah tempat seringnya berkumpulnya penduduk.

Kepadatan nyamuk sangat tergantung pada tempat perkembangbiakan dari nyamuk, sperti rawa-rawa, muara sungai, perkebunan, genangan air, hutan, kubangan seperti kubangan kerbau, limbah. Kepadatan nyamuk akan sangat berpengaruh pada intensitas gigitan dari nyamuk terhadap manusia, dimana kepadatan ini sendiri akan sangat tergantung dari tempat perkembiakkan nyamuk, geografis daerah, suhu dan musim (Depkes RI, 2007).

Kepadatan nyamuk juga di pengaruhi oleh suhu, suhu, suhu yang optimum berkisar 20-30 ${ }^{0} \mathrm{C}$, kelembaban yang rendah memperpendek umur nyamuk, meskipun tidak berpengaruh pada parasit, tingkat kelembaban minimal untuk nyamuk bisa hidup 60\%, hujan pada umumnya akan memudahkan perkembangan nyamuk dan terjadinya epedemi malaria, hujan yang di selingi panas akan memperbesar kemungkinan berkembangbiakkan nyamuk anopheles.
Nyamuk merupakan vektor penyakit daerah tropis seperti malaria, filariasis dan penyakit virus lainnya, diantaranya merupakan sebagai vektor penyakit malaria. Kesuburan daerah yang berarti terdapat orang dan ternak sebagai sumber makan nyamuk, rumah dan halaman serta kebun-kebun tempat hinggap dan istrahat nyamuk serta ada sumber air atau genangan-genangan air sebagai tempat perindukan nyamuk, pola aktivitas nyamuk anopheles mencari pakan darah berbedabeda atau sebagian besar aktif menghisap darah antara jam 18.00-22.00 dengan puncak aktivitasnya terjadi pukul 20.00, sedangkan menurut Damar, aktivitas menghisap darah sekitar pukul 19.00-21.00 di dalam dan di luar rumah.

\section{BAHAN DAN CARA KERJA}

Penelitian ini menggunakan pendekatan kuantitatif, dengan metode quasi experiment atau eksprimen semu. Populasi dalam penelitian ini adalah seluruh tempat perindukan nyamuk yaitu kandang ternak, kebun karet, dan lokasi tempat warga berkumpul malam hari, serta data pasien yang berobat di Puskesmas Tabalagan Kabupaten Bengkulu Tengah pada tahun 2012 berjumlah 65 orang.

Pengambilan sampel dalam penelitian ini dengan cara proportional random sampling yaitu sampel yang di ambil dari tiap-tiap populasi. Untuk menyempurnakan penggunaan Teknik sampel berstrata, besar sampel dihitung dengan rumus KNA, kepadatan nyamuk anopheles dan jumlah nyamuk yang di dapat.

Data primer didapatkan dari data puskesmas Tabalagan, menggunakan teknik wawancara, observasi langsung ke lapangan. Data sekunder diambil dari buku registrasi puskesmas Taba Lagan, pasien yang datang berobat di puskesmas Tabalagan Kabupaten Bengkulu Tengah yang diagnosis malaria.

Pengamatan penelitian difokuskan pada tiga tempat dengan menggunakan 
perangkap nyamuk Light Trap yaitu di perkumpulan penduduk, perkebunan karet, dan kandang kerbau.

Bahan-bahan untuk pemasangan perangkap nyamuk Light Trap adalah seng untuk melindungi lampu, lampu 20 watt berwarna putih untuk mengundang nyamuk, kawat saring untuk penangkal nyamuk agar tidak berpencar, sprong minyak atau kaleng bekas yang memungkinkan untuk tampungan nyamuk, kabel \pm 25 meter untuk pemasangan arus listrik ke lampu, botol bekas air mineral atau kain kasa untuk penampungan nyamuk, beberapa kayu untuk proses pembuatan tiang pada Light Trap dan alatalat lainnya.

Setelah proses pembuatan alat perangkap nyamuk light trap peneliti langsung membuat kotak penampungan nyamuk yang terkumpul pada setiap kali pemasangan light trap, hasil yang didapat dimasukkan ke dalam kotak penampungan nyamuk yang dibuat menggunakan stereophom yang dipotong dengan ukuran 20x30 cm, kain kassa $30 \mathrm{~cm}$ yang digunakan untuk memberi ruang udara terhadap nyamuk dan proses pengamatan nyamuk agar mudah untuk dilihat, dan juga memakai lem, solasi, dan jarum pentul untuk proses penyambungan kotak.

Setelah membuat kotak penampungan nyamuk peneliti menyiapkan makanan nyamuk selama proses pengumpulan yaitu dengan umpan air $\pm 1 / 2$ liter yang dicampurkan gula pasir 3 sdm. Proses pengumpanan dicelupkan kapas secukupnya ke dalam larutan air gula pasir lalu dimasukkan ke dalam kotak penampungan nyamuk.

\section{HASIL PENELITIAN}

Berdasarkan hasil penelitian, kasus malaria di lokasi kandang ternak sebanyak 6 orang, masin-masing tinggal di dekat kandang ternak yang berjarak 10 meter sampai 20 meter.

\section{Pemasangan Light Trap di Kandang Ternak}

Tabel 1. Tabel Hasil Analisis Pemasangan Light Trap di Kandang Ternak

\begin{tabular}{ccccc}
\hline Hari & Suhu & $\begin{array}{c}\text { Kelemba } \\
\text { ban }\end{array}$ & $\begin{array}{c}\text { Jumlah } \\
\text { (ekor) }\end{array}$ & $\begin{array}{c}\text { Jumlah } \\
\text { Anopheles }\end{array}$ \\
\hline 1 & $28^{\circ} \mathrm{C}$ & $75,8 \%$ & 21 & 1 \\
2 & $28^{\circ} \mathrm{C}$ & $78,5 \%$ & 15 & 3 \\
3 & $27^{\circ} \mathrm{C}$ & $75,5 \%$ & 25 & 2 \\
4 & $26^{\circ} \mathrm{C}$ & $90,5 \%$ & 15 & 2 \\
5 & $27^{\circ} \mathrm{C}$ & $93,5 \%$ & 10 & 1 \\
6 & $27,1^{\circ} \mathrm{C}$ & $80,5 \%$ & 14 & - \\
7 & $27,1^{\circ} \mathrm{C}$ & $80,3 \%$ & 8 & 2 \\
8 & $26,5^{\circ} \mathrm{C}$ & $75 \%$ & 7 & 3 \\
9 & $27^{\circ} \mathrm{C}$ & $93 \%$ & 5 & 1 \\
10 & $28^{\circ} \mathrm{C}$ & $92 \%$ & 7 & - \\
\hline \multicolumn{7}{c}{} \\
\hline
\end{tabular}

Keterangan :

a. Suhu rata-rata tertinggi $28^{\circ} \mathrm{C}$ terendah $26^{\circ} \mathrm{C}$

b. Kelembaban rata-rata tertinggi $93,5 \%$ terendah $75 \%$

c. Jumlah nyamuk yang tertangkap 127 ekor

d. Jumlah nyamuk Anopheles Sp 15 ekor $\mathrm{KNA}=\frac{15}{127}=0,118$

Tabel 2 Kepadatan Nyamuk Anophles di Kandang Ternak

\begin{tabular}{lc}
\hline \multicolumn{1}{c}{ Kelompok } & Jumlah \\
\hline Nyamuk Anopheles & 15 \\
Nyamuk yang tertangkap & 127 \\
\hline Hasil & $\mathbf{0 , 1 1 8 ~ \% ~}$ \\
\hline
\end{tabular}

Pemasangan Light Trap di Perkebunan Karet

Tabel 3 Hasil Analisis Pemasangan Light Trap di Perkebunan Karet

\begin{tabular}{|c|c|c|c|c|}
\hline Hari & Suhu & Kelembaban & $\begin{array}{c}\text { Jumlah } \\
\text { (ekor) }\end{array}$ & $\begin{array}{c}\text { Jumlah } \\
\text { Anopheles }\end{array}$ \\
\hline 1 & $27^{\circ} \mathrm{C}$ & $75,8 \%$ & 10 & 2 \\
\hline 2 & $28^{\circ} \mathrm{C}$ & $80,5 \%$ & 12 & - \\
\hline 3 & $27^{\circ} \mathrm{C}$ & $75,5 \%$ & 20 & 1 \\
\hline 4 & $26^{\circ} \mathrm{C}$ & $90 \%$ & 5 & - \\
\hline 5 & $27^{\circ} \mathrm{C}$ & $80,5 \%$ & 11 & 1 \\
\hline 6 & $26^{\circ} \mathrm{C}$ & $93,5 \%$ & 4 & 1 \\
\hline 7 & $27^{\circ} \mathrm{C}$ & $80,3 \%$ & 15 & 3 \\
\hline 8 & $26^{\circ} \mathrm{C}$ & $78,5 \%$ & 13 & - \\
\hline 9 & $28^{\circ} \mathrm{C}$ & $93 \%$ & 8 & 1 \\
\hline 10 & $26^{\circ} \mathrm{C}$ & $92 \%$ & 9 & - \\
\hline \multicolumn{3}{|c|}{ Jumlah } & 96 & 9 \\
\hline
\end{tabular}

Keterangan:

a. Suhu rata-rata tertinggi $28^{\circ} \mathrm{C}$ terendah $26^{\circ} \mathrm{C}$

b. Kelembaban rata-rata tertinggi $93,5 \%$ terendah $75,5 \%$

c. Jumlah nyamuk yang tertangkap 96 ekor

d. Jumlah nyamuk Anopheles Sp 9 ekor

$$
\mathrm{KNA}=\frac{9}{96}=0,093
$$


Tabel 4 Kepadatan Nyamuk Anopheles di

Perkebunan Karet

\begin{tabular}{lc}
\hline \multicolumn{1}{c}{ Kelompok } & Jumlah \\
\hline Nyamuk Anopheles & 9 \\
Nyamuk yang tertangkap & 96 \\
Hasil & $\mathbf{0 , 0 9 3 \%}$
\end{tabular}

Dari hasil pengamatan di kebun karet terdapat 3 orang terkena malaria, masingmasing di sebabkan akibat di gigit nyamuk di waktu menyadap karet, dan waktu menjelang pagi selama \pm 1 minggu.

\section{Pemasangan Light Trap di Tempat Perkumpulan Penduduk}

Tabel 5 Hasil Analisis Pemasangan Light Trap di Perkumpulan Penduduk

\begin{tabular}{|c|c|c|c|c|}
\hline Hari & Suhu & Kelembaban & $\begin{array}{c}\text { Jumlah } \\
\text { (ekor) }\end{array}$ & $\begin{array}{c}\text { Jumlah } \\
\text { Anopheles }\end{array}$ \\
\hline 1 & $27^{\circ} \mathrm{C}$ & $80 \%$ & 6 & - \\
\hline 2 & $28^{\circ} \mathrm{C}$ & $80,5 \%$ & 4 & - \\
\hline 3 & $28^{\circ} \mathrm{C}$ & $82 \%$ & 1 & 1 \\
\hline 4 & $26^{\circ} \mathrm{C}$ & $90 \%$ & 2 & - \\
\hline 5 & $27^{\circ} \mathrm{C}$ & $93 \%$ & 3 & 2 \\
\hline 6 & $26^{\circ} \mathrm{C}$ & $91 \%$ & - & - \\
\hline 7 & $26^{\circ} \mathrm{C}$ & $75 \%$ & 4 & - \\
\hline 8 & $27^{\circ} \mathrm{C}$ & $93 \%$ & 2 & - \\
\hline 9 & $26^{\circ} \mathrm{C}$ & $80 \%$ & 13 & - \\
\hline 10 & $26,5^{\circ} \mathrm{C}$ & $85 \%$ & 3 & 1 \\
\hline \multicolumn{3}{|c|}{ Jumlah } & 38 & 4 \\
\hline
\end{tabular}

Keterangan :

a. Suhu rata-rata tertinggi $28^{\circ} \mathrm{C}$ terendah $26^{\circ} \mathrm{C}$

b. Kelembaban rata-rata tertinggi $93 \%$ terendah $75 \%$

c. Jumlah nyamuk yang tertangkap 38 ekor

d. Jumlah nyamuk Anopheles Sp 4 ekor

$$
\mathrm{KNA}=\frac{4}{38}=0,105
$$

Tabel 6 Kepadatan Nyamuk Anopheles di perkumpulan penduduk

\begin{tabular}{lc}
\hline \multicolumn{1}{c}{ Kelompok } & Jumlah \\
\hline Nyamuk Anopheles & 4 \\
Nyamuk yang tertangkap & 38 \\
\hline Hasil & $\mathbf{0 , 1 0 5 \%}$ \\
\hline
\end{tabular}

Hasil penelitian di temukan 1 orang kasus malaria, hal ini disebabkan kebiasaan warga berkumpul di malam hari.
Tabel 7. Hasil Kepadatan Nyamuk Anopheles

\begin{tabular}{lcc}
\hline \multicolumn{1}{c}{ Tempat } & Jumlah & $\begin{array}{c}\text { Nyamuk } \\
\text { anopheles }\end{array}$ \\
\hline Kandang kerbau & 0,118 & Terbanyak \\
Perkebunan karet & 0,093 & Sedikit \\
Perkumpulan penduduk & 0,105 & Sedang \\
\hline
\end{tabular}

Keterangan: Hasil dari kepadatan nyamuk anopheles yang tertangkap menggunakan light trap diantaranya lebih banyak terdapat di kandang kerbau yaitu mencapai $0,118 \%$, dan yang terkena malaria 6 orang.

Hasil wawancara terhadap warga yang kasus malaria di Desa Tabalagan di tiga tempat, kandang kerbau, perkebunan karet dan perkumpulan penduduk sebagai berikut:

1. Hasil wawancara salah satu warga yang tinggal di dekat kandang kerbau di Desa Tabalagan Kabupaten Bengkulu Tengah.

"di tapan cik kadis kak ade due yang kene malaria. Anak cik, beni yang umur $e$ sekitar 23 tahun, dengan cik jugek, udem e di arah parak bukit na ade sikok, tapi sikitar 8 bulan arai na, datuk cik arai na jugek kene termasuk kawan e yang sesame ngisul kebau ,pailah kene e tpi die terlalu parah nian, baik cik dan dapat kabar $e$ yang lain $e$ thu gara-gara ngenjuk upan kebau di waktu endak magrib, udem e galak keluo uma pas-pas udem makan na, udem magrib lah kire-kire e. (di tempat ayuk kadis ada dua yang terkena malari termasuk ayuk dan anak ayuk, beni yang berumur 23 tahun, setelah itu di daerah perbatasan desa bukit dan tabalagan ada satu yang terkena malaria, tetapi sekitar 8 bulan yang lalu, kakek ayuk juga kena malaria termasuk kawannya yang samasama memilihara kerbau, baru sekitar seminggu ini terkena malaria tetapi malaria yang di deritanya termasuk malaria rendah, mayoritas yang terkena malaria di karenakan tinggal di dekat kandang kerbau yang berjarak 10 sampai 20 meter, terutama ayuk sendiri dan yang lain nya terdengar bahwasanya di sebabkan pada waktu memberi makan kerbau dan keluar 
di malam hari, itulah asal mula datang malaria).

2. Hasil wawancara dengan warga di sekitar perkebunan karet.

"kak na wak arai na ade jugek kene malaria, wak ingat nian wak dapat penyakit na karne wak nakik die pakai pelembab yang galak yang wang lain na pakai, kadang-kadang wak diam ke bae nyamuk ngigit tangan wak na,kejadian kak berlangsung seminggu,udem e mulai timbul die lemak badan lah, kadan-kadang panas dingin, die selero makan, ngikil, kate wang q kene malaria,tapi e lame-lame sembuh jugek e.q kak datuk kuris ,q na yung jugek sapai-sapai nyamuk na ta kenyang-kenyang latak e naymuk makan darah ku kak,nyamuk banyak nian kalu lagi nakik na, ngingit sekendak utak $e$ bae,semenjak itu lah datuk kak kene pnyakit malaria kate wang na. Ao do $q$ jugek arai na aku nalak ijat parah, mank nian naymuk banyak nian ngingit di badanku,pas malam na $q$ die lemak badan,panas dingin, die selero makan,ngingil, men die jenguk- jenguk ciri khas malaria nian na" (kemaren saya terkena malaria, saya mendapat penyakit malaria ketika menyadap karet, ketika itu saya tidak perna memakai pelembab supaya nyamuk tidak berani mendekat seperti kawan-kawan yang lain nya. Saya kuris saya juga perna kurang enak badan, badan menggigil, terkadang panas dingin, tidak selera makan, kata orang itu gejala malaria tetapi lama kelamaan sembuh sendiri, datang penyakit malaria di karenakan nyamuk menggigit tanganku sampai kenyang nyamuk itu sendiri menghisap darahku ketika aku menyadap karet. Iya bang aku kemaren kena malaria setelah itu di suntik oleh pak edi orang puskesmas tabalagan, aku dapat penyakit itu setelah aku mencari biji karet, malamnya mulai aku kurang enak badan).
3. Hasil wawancara di tempat perkumpulan penduduk
"ao due bulan yang lalu bro kirekire e, aku kene malaria seingatku karne aku galak begadang die bebaju pule kadang na, latak hobi maeng song, nyamuk ngigitku main tepuk baek sapai mati" ( iya sekitar dua bulan yang lalu saya terkena malaria, itu pada waktu aku sering begadang).

\section{PEMBAHASAN}

Dari hasil observasi lapangan, kejadian malaria disebabkan adanya tempat perindukan nyamuk terdapat di selokan, tempat pengubangan kerbau, tempat penampungan getah karet atau tempurung karet, dan tempat pemukiman penduduk yang dekat dengan hutan.

Identifikasi nyamuk tangakapan hasil penelitian terlebih dahulu dimasukkan kedalam kotak yang dibuat bersamaan dengan alat light trap, nyamuk dimasukkan dari hasil yang didapat perhari.

Nyamuk dimasukkan kedalam kotak, jumlah yang tertangkap dicatat setiap harinya kemudian nyamuk yang dimasukkan kedalam kotak dibawa dan diidentifikasi ke laboratorium dan peneliti mengamati jenis nyamuk yang ingin diamati.

Penangkapan nyamuk di dalam kotak light trap dengan memakai sedotan yang dinamakan aspirator yaitu alat khusus penangkapan nyamuk supaya nyamuk yang ingin diteliti bisa utuh dari keseluruhan tubuhnya, untuk membantu agar peneliti bisa menganalisis jenis nyamuk yang diinginkan, peneliti meletakkan sedikit chloroform khusus untuk nyamuk supaya ketika diteliti nyamuk tidak dengan mudah bergerak. Setelah proses nyamuk sudah diteliti, nyamuk dimasukkan kembali ke dalam kotak.

Jumlah nyamuk yang tertangkap menggunakan light trap di kandang kerbau 127 ekor, di perkebunan karet 96 ekor dan di perkumpulan penduduk 38 ekor. Dapat disimpulkan kepadatan nyamuk di desa Tabalagan terbanyak di kandang kerbau dengan persentase $0,118 \%$. Maka dari itu masyarakat di desa Tabalagan lebih 
mewaspadai tempat pertenakan kandang kerbau dengan cara membersihkan dan menyemprot nyamuk-nyamuk yang berada di kandang kerbau.

Proses dari pengamatan adanya angka kejadian malaria di desa Tabalagan kabupaten Bengkulu Tengah dan dari hasil data yang peneliti dapat di puskesmas Tabalagan sebanyak 65 orang penderita malaria klinis. (puskesmas Tabalagan 2012). Dengan ditemukan nyamuk anopheles dari tiga tempat penelitian kandang kerbau, kebun karet, dan pekumpulan penduduk adalah sebagai berikut :

\section{Di kandang kerbau}

Dari hasil pengamatan dan analisis penelitian, yang terkena penyakit malaria sebanyak 6 orang, dari masing-masing yang terkena malaria mayoritas masyarakat yang rumahnya tinggal di dekat kandang kerbau, yang berjarak antara 10 meter sampai 20 meter, sehingga nyamuk yang di kandang kerbau lebih mudah menggigit warga yang tinggal di dekat kandang. Dari hasil analisis penelitian, ditemukan nyamuk anopheles 15 ekor $(0,118 \%)$, nyamuk yang ditemukan berukuran lebih besar dibandingkan dengan dua lokasi lainnya, hal ini diduga karena tempat makanan nyamuk lebih banyak dan tempat perkembangbiakan lebih optimal. Tempat makanannya bisa dikotoran kerbau dan darah kerbau, waktu aktivitasnya pukul 18.00 sampai 22.00 wib, nyamuk lebih banyak ditemukan di kandang kerbau, dikarenakan suhu di kandang kerbau ratarata $90 \%$, di karenakan nyamuk lebih suka di tempat yang lembab.

Hal ini sesuai dengan teori yang menyatakan bahwa faktor lingkungan dalam hal ini adalah tempat perindukan nyamuk di tempat peternakan sebagian besar berkaitan dengan aspek klimitologi, seperti suhu udara, kelembaban udara, hujan, tempat peristirahatan, dan tempat makanan yang mendukung (Depkes RI, 2003).
Hasil penelitian ini juga didukung oleh hasil penelitian yang dilakukan oleh Suharmasto menyatakan bahwa masyarakat yang bermukiman berjarak kurang dari $2 \mathrm{~km}$ dari tempat perindukan nyamuk mempunyai risiko 2,98 kali untuk terserang malaria dibandingkan dengan masyarakat yang bermukim lebih $2 \mathrm{~km}$ dari tempat perindukan nyamuk. Tempat perindukan nyamuk adalah tempat dimana nyamuk dapat hidup dan berkembang biak. Tempat hinggap nyamuk dapat di rumputrumput, semak-semak yang berdekatan dengan genangan air.

2. Perkebunan karet

Dari pengamatan dan hasil penelitian yang terkena malaria sebanyak 3 orang, masing-masing akibat menyadap karet, waktu menggigitnya di pagi hari dengan waktu menggigit nya \pm 1 minggu, setelah itu penderita mulai terasa di serang malaria, dari hasil analisis penelitian, di temukan jenis nyamuk anopheles 9 ekor $(0,93 \%)$. nyamuk mayoritas berukuran kecil, karna nyamuk di perkebunan karet ciri-ciri nya berbentuk kecil di bandingkan dengan tempat-tempat lain yang tidak keseluruhan berukuran kecil dan waktu aktivitas nyamuk jam 5.00 menjelang pagi, di karenakan waktu menggigit dan mencari nutrisi telurnya di waktu menjelang pagi.

Hal ini sejalan dengan adanya berbagai jenis pekerjaan yang mempunyai hubungan dengan malaria, karena pekerjaan tersebut mempunyai faktor risiko dan memberi peluang untuk kontak dengan nyamuk seperti di perkebunan. (Ahmadi, 2005).

Hal ini juga menyatakan faktor lingkungan fisik seperti halnya di perkebunan yang berkaitan dengan kondisi tempat perindukan nyamuk, geografis, iklim, tempat peristirahatan, suhu, tempat perindukan dan kondisi tempat yang memiliki ciri khas tersendiri terhadap jenis nyamuk tersebut (Depkes RI, 2003).

3. Perkumpulan penduduk

Dari hasil pengamatan dan analisis penelitian di temukan 1 orang yang terkena 
malaria, kasus malaria ini disebabkan karena warga yang kebiasaan berkumpul di malam hari yang tidak memakai baju ketika bermain song, dari analisis penelitian ditemukan jenis nyamuk anopheles 4 ekor $(0,105 \%)$ dan waktu aktivitasnya pada pukul menjelang magrib sampai pukul 22.00 wib untuk menghisap darah, di atas pukul 22.00 sebagian besar nyamuk lebih mencari tempat istirahat di tempat gantungan pakaian, dinding, air yang tergenang (limbah) dan tempattempat yang lembab yang di sukai nyamuk, nyamuk yang ditemukan berukuran kecil.

Faktor aktivitas nyamuk tergantung tempat lokasi perindukannya, seperti di rumah, perkarangan rumah dan tempattempat yang lembab yaitu, penumpukkan sampah, selokan air yang tidak terawat dan gantungan baju yang basah akan meningkatkan timbulnya penyakit malaria (Depkes RI, 2003).

Hal ini sejalan dengan penelitian yang dilakukan oleh Elvi Natalya (2012), kebiasaan masyarakat dalam beraktivitas malam di luar rumah dapat meningkatkan risiko malaria, hal ini desebabkan oleh adanya beberapa spesies anopheles yang menghisap pakan darah pada waktu menjelang magrib dengan akitivitas puncak pada kisaran pukul 22.00 wib.

Dari hasil pengamatan penyebab penyakit malaria disebabkan nyamuk anopheles yang berperilaku menyukai menggigit dan menghisap darah manusia.

Aktivitas nyamuk jantan dengan nyamuk betina sangat berbeda, nyamuk jantan tidak menggigit dan menghisap darah, sedangkan nyamuk betina menggigit dan menghisap darah yang digunakan untuk memberikan nutrisi bagi telurtelurnya.

Dari hasil penangakapan semua nyamuk pada tiga lokasi penelitian, peneliti menggunakan mikroskop untuk mengidintifikasi nyamuk anopheles atau bukan dari hasil penangkapan tersebut. Identifikasi nyamuk yaitu dengan melihat bagian kepala yaitu proboscis, palpus, dan antena. bagian dada mengamati sepasang sayap dengan urat-urat sayap yang tampak jelas, perbedaan-perbedaan dengan jenis nyamuk lainnya, jika nyamuk anopheles palpus sama panjang dengan proboscis, memiliki 1 proboscis,sepasang 2 palpus dan sepasang 2 antena, sedangkan nyamuk lainnya seperti aedes mempunyai proboscis, antena, palpus memiliki 1, ketiga-tiganya sama panjang.

\section{KESIMPULAN}

Frekuensi nyamuk yang tertangkap dengan mengunakan light trap yaitu kandang kerbau 127 ekor ciri-ciri nyamuk lebih besar dan aktivitas nyamuk antara pukul $18.00-22.00$ wib, perkebunan karet 96 ekor, nyamuk yang di dapat berukuran kecil, aktivitas nyamuk mencari pakan darah yaitu menjelang pukul 05.00 wib, dan perkumpulan penduduk 38 ekor, nyamuk yang di dapat berukuran kecil, aktivitas nyamuk menggigit antara pukul 18.00 - 21.00 wib. keseluruhannya 261 ekor. Dengan suhu rata-rata tertinggi $28^{\circ} \mathrm{C}$ terendah $26^{\circ} \mathrm{C}$. Kelembapan rata-rata tertinggi $93,5 \%$ terendah $75 \%$.

Kepadatan nyamuk anopheles yang tertangkap dengan Light trap diantaranya terdapat di kandang kerbau 15 ekor anopheles $(0,118 \%)$, perkebunan karet 10 ekor anopheles $(0.104 \%)$ dan perkumpulan penduduk 4 ekor anopheles $(0,105 \%)$. Dari hasil penelitian ini, dapat disimpulkan bahwa keberadaan nyamuk anopheles lebih banyak terdapat di kandang kerbau, yaiut 15 ekor $(0,118 \%)$.

Kejadian malaria di desa Tabalagan dikarenakan adanya ditemukan jenis nyamuk anopheles sp pada semua titik lokasi pengamatan, pada warga yang terdapata kandang ternak (kandang kerbau) terdapat 6 kasus malaria, pada warga yang tinggala disekitar perkebunan karet terdapat 3 kasus malaria dan pada tempat perkumpulan warga malam harai terdapat 1 kasus malaria. 


\section{DAFTAR RUJUKAN}

Departemen Kesehatan RI. 2003, Modul Epidemiologi Malaria. Jakarta: Direktorat jendral pemberantasan penyakit menular dan penyehatan Lingkungan hidup pemukiman.

2003. Survei Dinamika Penularan Malaria. Jakarta: Direktorat Jenderal Pemberantasan Penyakit Menular dan Penyehatan Pemukiman Lingkungan.

2009. Informasi Umum Malaria. Jakarta: Direktorat Jenderal Pengendalian Penyakit dan Penyehatan Lingkungan.
Puskesmas Tabalagan Kabupaten Bengkulu Tengah 2012. Laporan Tahunan Dinas Kesehatan. Kabupaten Bengkulu Tengah.

Dinas Kesehatan Bengkulu Tengah, 2011. Profil Kesehatan Kab.Bengkulu Tengah 2011. Bengkulu Tengah: Dinkes Bengkulu Tengah.

Prabowo, 2004. Malaria, Mencegah dan Mengatasinya. Jakarta: Puspa Swara.

Widoyo, 2005. Penyakit Tropis, Epedemiologi, Penularan, Pencegahan dan Pemberantasanny, Penerbit Erlangga 